\title{
Bank Characteristics and Liquidity Transformation: The Case of GCC Banks
}

\author{
Ritab Al-Khouri \\ Correspondence: Ritab Al-Khouri, Professor, Department of Finance and Economics, Qatar University, Qatar. \\ E-mail: r.al-khouri@qu.edu.qa
}

Received: September 21, 2012

Accepted: October 24, $2012 \quad$ Online Published: October 31, 2012

doi:10.5539/ijef.v4n12p114

URL: http://dx.doi.org/10.5539/ijef.v4n12p114

\begin{abstract}
This paper uses a simple measure of liquidity creation to examines empirically the effect of bank capital and other micro and macro-characteristics on liquidity creation. We apply the analysis to data from a sample of 43 banks operating in 6 of the countries comprising the GCC (Bahrain, Kuwait, Oman, Qatar, Saudi Arabia and the United Arab Emirates) market over the period 1998-2008. Large banks with high capital seem to produce most of the liquidity by the banking sector in the GCC market. However, the negative relationship between profitability and liquidity created by banks indicate either high loan losses or high cost of intermediation.
\end{abstract}

Keywords: liquidity creation, capital, micro and macro factors and banking

JEL Codes: G32, G20, and G21

\section{Introduction}

The chaos and disorder that hit the world financial markets lately has been mainly about liquidity. Since the problem started, late 2007, there has been a noticeable disruption to the traditional mechanisms of liquidity creation and transmission. The major task of liquidity transformation by the banking sector, through accepting short-term liquid liabilities in the form of deposits and making longer-term loans which are illiquid, directly affects the successful transfer of funds from savings to investment and therefore, plays a fundamental role in facilitating production.

This paper uses a simple measure of liquidity creation to examine empirically the effect of bank capital and other micro and macro-characteristics on liquidity creation. We apply the analysis to data from a sample of 43 banks operating in 6 of the countries comprising the GCC (Bahrain, Kuwait, Oman, Qatar, Saudi Arabia and the United Arab Emirates) market over the period 1998-2008.

The research focuses on the one function of the banking sector which is liquidity creation. The paper has three objectives; first, it examines the effect of bank capital on liquidity creation. Second, study the role of banks' Government ownership in affecting the liquidity level of these banks. Finally, determine the relationship between banks' liquidity creation and their profitability.

Most of the literature dealt with the issue, the extent to which banks perform the function of liquidity creation, in a theoretical framework and very few papers have subjected these theories to systematic empirical examination. The role of the banks as liquidity creators did not receive much attention in the developed markets and no attention in the GCC market. Therefore, comprehensive empirical research on bank liquidity creation is absent. This makes it difficult to address many questions of interest to research and policy makers. For example, this research will help us show how much liquidity does the banking sector in the GCC market creates. What are the characteristics of banks that perform more liquidity?

In fact one of the greatest policy challenges for the GCC had been managing liquidity inflows and speculative funds. Funds flew to the region due to speculation on currency reform and the continuation of an expansionary fiscal policy, added to this the cuts in interest rates which lead to additional credit growth. Although increased wages for public sector employees lead to an increase in private sector deposit base in the banking system, it also has increased the ability of individuals to borrow. This had the effect of increasing the gap between deposits and loans, and expose banks to high liquidity risk. Therefore, this paper might have important policy implications for the countries in the region. 
This paper is organized as follows: The second section will discuss the related literature, while section 3 concentrates on the sources of data and the methodology implemented. Section 4 presents the results of our analysis and the final section conclusions.

\section{Literature Review}

According to the modern theory of financial intermediation, banks perform two central roles in the economy, the first role is liquidity creation (e.g. Diamond and Dybvig (1983) and Kashyap, Rajan, and Stein (2002)), and the second is risk transformation (e.g Diamond 1984). Empirical research has focused mainly on banks' role as risk transformers.

Commercial banks as financial institutions take funds in the form of deposits from the public and provide financing to the demanders of funds in the form of loans. Therefore, banks by converting liquid liabilities into illiquid assets facilitate investment and production and contribute to the economic growth. Liquidity in the banking sector is associated mainly with the availability of funds, or the guarantee that funds will be available with on and off balance sheet commitments as they mature. These commitments are met through the ability of the institution to borrow or by their assets which is readily exchanged into cash without losses. Because of the mismatch between the banks' assets and their liabilities however, banks suffer from capital structure fragility. The risk associated with illiquidity may increase if cash flow from interest and from principal related to assets, liabilities and off balance sheet items are mismatched. Diamond and Dybvig (1983), for example pointed out that one of the key reasons why banks are fragile, is their role in transforming maturity and providing insurance with regard to depositors' potential liquidity needs.

Deep and Schaefer (2004) define the liquidity transformation gap as (liquid liabilities - liquid assets)/Total assets and apply it to data on the 200 largest U.S. banks for the period between 1997 and 2001. They consider all loans with maturity of one year or less to be liquid, and they explicitly exclude off-balance sheet activities because of their contingent nature. They find that for the sample of large banks, the LT gap is about $20 \%$ of total assets on average. The authors conclude that these banks do not appear to create much liquidity.

Berger and Bouwman (2008), implement four measures of liquidity creation and apply them to data on U.S. banks over the period 1993-2003. They find that bank liquidity creation increased every year and exceeded $\$ 2.8$ trillion in 2003. Large banks, multibank holding company members, retail banks, and recently merged banks create the most liquidity. Bank liquidity creation is positively correlated with bank value. The researchers also find that the relationship between capital and liquidity creation is positive for large banks and negative for small banks.

Recent theories in the literature provide conflicting predictions on the effect of bank capital on its liquidity creation. One strand in the literature predict that bank capital reduces bank liquidity creation, Diamond and Rajan (2000) while Gorton and Winton (2000), show that capital requirements may have an important social cost because they reduce the ability of banks to create liquidity. They show that capital ratio might reduce liquidity creation through the crowding out of deposits.

Skander J. Van den Heuvel, (2007), argue that since Capital requirements limit the fraction of bank assets that can be financed by issuing deposit-type liabilities, capital requirement regulation imposes important cost because it reduces the ability of banks to create liquidity by accepting deposits.

Other theories predict that bank capital increases bank liquidity through its ability to absorb risk. Under the "risk absorption" hypothesis, higher capital improves the ability of banks to create liquidity. Diamond and Dybvig (1983), Allen and Gale (2004) for example argue that liquidity creation exposes banks to risk. The more liquidity that is created, the greater is the probability of losses associated with having to dispose of illiquid assets to meet the liquidity demands of customers. Additionally, Bhattacharya and Thakor (1993) and, Coval and Thakor (2005) emphasized the point that bank capital absorbs risk and expands banks' risk-bearing capacity. Based on this argument, higher capital ratios may allow banks to create more liquidity.

The GCC region is one of the regions that were affected negatively by the international financial crises. During the period proceeded the crises, monetary base in the region increased tremendously which increased the ability of banks to lend. In addition, the decrease in interest rates on credits led to acceleration in credit growth. Most of the big banks in the region expanded their lending activity aggressively. The nature of liquidity in the region though was short term and mostly speculative. With the increase in inflation in 2006-2007, real interest rate became negative across the region which increased the incentives for more borrowing. Although deposits increased, credit growth was stronger which caused loans to deposits ratio across the region to increase. This leads to a big gap and mismatch between deposits and loans, and consequently exposed banks to high liquidity 
risk and where banks become more vulnerable to liquidity shocks arising from the liability side of their balance sheets. If for any reason large fraction of depositors demand cash, the bank may need to liquidate its illiquid assets. This liquidation consequently might involve loss of value and in the extreme case liquidity shortage may turn into a solvency.

The primary objectives of this research are to investigate the effect of bank capital and government ownership on liquidity creation. We apply the analysis to data on a sample of banks operating in 6 of the countries comprising the GCC market over the period 1998-2008. This paper also investigates the characteristics of banks that transform more liquidity in the GCC. Finally, we will investigate whether there is any relationship between banks liquidity creation and their profitability.

\section{Data and Methodology}

\subsection{Data Source}

Yearly data from the annual reports of 43 commercial banks operating in the GCC countries over the period $1998-2008$ is collected. Only banks that have data available for all these years under study are included in the sample.

Data on inflation, economic growth and GDP per capita are taken from the World Development Indicators. The data on stock market capitalization are taken from each stock market separately.

\subsection{Variables}

\subsubsection{Measuring Liquidity Transformation}

To measure liquidity creation, it is needed to determine the difference between the liquidity of the bank assets and its liabilities. Therefore, following Akash Deep and Guido Schaefer (2004), our measure of liquidity is the difference between liquid liabilities and liquid assets as a percentage of total assets, or liquidity transformation gap (LT gap). The ratio measures the net amount of liquidity transformation a bank performs as a function of its total assets. This definition of LT gap reflects the liquidity of both sides of the balance sheet and therefore even banks that appear equally liquid on the asset side may have different LT gaps depending on their financing structure. We are aware that this is a simple measure and we have to use not just on balance sheet items but also the off balance sheet items, however, not enough data is available in the annual reports of the banks in these countries. Therefore, we had to stick with this simple measure:

$$
L T G=(L A-L L) / G T A
$$

Where:

LTG=liquidity transformation gap

LA: Are liquid assets

$\mathrm{LL}=$ Liquid liabilities

GTA $=$ Gross total assets

Variable liquidity gap measures divided by GTA. The normalization by GTA is necessary to make the dependent variables meaningful and comparable across banks and to avoid giving unnecessary weight to the largest institutions. The higher the gap, the greater is the liquidity transformation performed by the bank.

Liquid liability are defined as the items in the balance sheets which have maturity of less than one year we include demand deposits, money market deposit accounts foreign deposits, and any funds borrowed with maturity of less than one year. Liquid assets are the cash, government and non-government securities, acceptances, and all loans with maturity of less than one year.

\subsubsection{Bank Capital}

Bank Capital $=$ book value of equity divided by total assets $(E Q U I T Y)$

High ratio of bank capital means lower degree of risk. It shows how much of bank's assets values may decline before the position of its depositors and other creditors is endangered. Recent theories in the literature provide conflicting predictions on the effect of bank capital on its liquidity. One strand in the literature predict that bank capital reduces bank liquidity creation, while other theories predict that bank capital increases bank liquidity through its ability to absorb risk. Several studies find that the decline in bank capital ratios arising from loan losses in the late 1980s and early 1990s contributed significantly to the reduction in lending (e.g., Peek and Rosengren 1995). This finding is consistent with a positive relationship between capital and liquidity creation during a period of distress. 
Other studies in the literature found that the leverage requirement, by U.S regulators early 1990s and the Basel 1 risk adjusted capital standard contributed to the decrease in lending, consistent with the hypothesis of a negative effect of bank capital on liquidity creation (e.g., Berger and Udell 1994, Hancock, Laing, and Wilcox 1995, Peek and Rosengren 1995). In addition, Gatev and Strahan (2005) find that a higher bank capital ratio tends to be followed by greater loans and deposits (which may increase liquidity creation) and greater liquid assets and non-deposit liabilities (which may reduce liquidity creation).

Therefore, financial fragility-crowding out hypothesis: Suggests a negative relationship between capital_and liquidity transformation, while the "risk absorption" hypothesis suggests a positive relationship between capital and liquidity transformation.

\subsubsection{Credit Risk}

Measured by the volatility of ROA $\left(\sigma_{\mathrm{ROA}}\right)$ reflects the risk of default in repayment of bank loans, is closely tied to liquidity transformation because cumulative default risk tends to rise over time. Credit expansion in the GCC market has been very rapid over the past several years, driven in large part by strong economic growth. The rapidity of this credit growth has led to questionable credit risk assessment practices. We expect therefore, an adverse effect of credit risk on the liquidity transformed by GCC banks.

\subsubsection{Profitability (ROA)}

The higher the profitability of the bank, the higher its ability to transform liquidity. We will use the one period lag of the return on asset

\subsubsection{Bank size: Ln (TA)}

The log of total assets, represented by SIZE, is included as an additional variable to capture possible size affects such as sophistication of risk management skills.

\subsubsection{Government Ownership (GO)}

We expect that banks with higher government ownership are more able to create liquidity. The government might be working as a guarantee for the banks if something jeopardizes the deposits of the banks.

In addition, six external determinants are examined to study the impact of environment and country specific characteristics on bank's liquidity transformation.

\subsubsection{Growth in Real GDP (GGDP)}

It measures the total economic activity in the economy. It is expected to be positively related to Bank liquidity transformation. According to the literature of financial sector development and economic growth, growth in GDP is positively associated with bank performance and growth in credit.

\subsubsection{Inflation (Inf)}

Previous research documented a positive relationship between inflation and bank profitability. If inflation is anticipated, then high inflation implies high interest on loans, and consequently high income. If inflation is not anticipated, then the effect of the increase in inflation might increase bank cost and have a negative effect on profitability if banks are unable to adjust accordingly.

\subsubsection{Stock Market Capitalization to GDP (SCAP)}

Measures the development of the stock market, and its importance in financing the economy. Demirguc-Kunt and Huizinga (1999) found stock market capitalization to bank assets, to be negatively related to margins suggesting that relatively well-developed stock markets can substitute for bank finance. We therefore expect, this variable to be negatively related to bank's performance.

\subsubsection{Degree of Market Concentration (Con)}

It is measured as the total assets held by the three largest commercial banks in the country divided by the total assets of all commercial banks in the country. One documented hypothesis in the literature argues that high market concentration causes less competition between banks, which leads, consequently to higher profitability. This hypothesis referred in the literature as structure conduct performance (Gilbert, 1984).

\subsection{Methodology and Empirical Models}

To measure the impact of bank capital and government ownership indicators on liquidity transformation while controlling for bank specific characteristics and macroeconomic indicators on the GCC region, we estimate the following model:

$$
L T G_{i, k, t}=f\left(C_{i, k, t}, G_{i, k, t}, Z_{i, k, t}, M_{k, t}\right)
$$


Where LTG $_{i, k, t}$ is the liquidity transformation gap of bank $\mathrm{i}$ and country $\mathrm{k}$ during period t. $\mathrm{C}_{\mathrm{i}, \mathrm{k}, \mathrm{t}}$ is a measure of bank capital ratio for bank I and country $k$ at time t. $G_{i, k, t}$ is the government ownership in bank I and country $k$ at time t. $Z_{i, k, t}$ is a vector of bank specific characteristics of bank $I$ in country $k$ and time period t. $M_{k, t}$ is a vector of Macroeconomic indicators for country k during the period $t$.

In this study we use time series cross sectional data (i.e. panel data) rather than looking at cross sectional data. Time series data provides information about liquidity transformation overtime which is ignored in the cross sectional analysis. In addition, Since our sample is relatively small, given the limited number of commercial banks in the region with information, the use of panel data increases the sample size and hence the degrees of freedom.

In order to test our hypotheses, we have developed the following model:

$$
Y_{i t}=a_{o i t}+b k_{i t} X k_{i t}+c d_{j t} X d_{i t}+\varepsilon
$$

where $i$ refers to an individual bank; $t$ refers to year; $j$ refers to the country in which bank $I$ operates; $Y_{i t}$ the dependent variable that refers to the liquidity creation measure and is the observation of a bank $i$ in a particular year $t ; X k$ represents the internal factors/determinants of a bank liquidity; $X d$ represents the Macro factors/determinants which control for market condition and the differences between country's specific and unique characteristics; $\varepsilon$ is an error term.

After testing for the best fit to our data, we estimated the model by ordinary least square regression analysis to determine the most important variables that affect the liquidity transformed by GCC banks.

Our expanded regression model looks finally as the following:

$$
L T G_{i t}=a_{0 t}+a_{1 i t} E Q U I T Y+a_{2 i t-l} \sigma_{\text {ROA }}+a_{2 i t} L n T A+a_{3 i t} G G D P+a_{4 i t} S C A P+a_{5 i t} I N F+a_{6 i t} C O N+a_{7 i t} G O+
$$

\section{Empirical Results}

Using the panel data sets on banks residing on the GCC market over the period 1998-2008, we regress the liquidity creation measures for each bank-year observation on the bank's equity capital ratio and a number of control variables to examine whether the financial fragility effect versus the risk absorption effect dominates empirically.

Table 1 shows the results of the summary statistics on the variables under investigation, while table 2 shows the correlation between our variables under investigation. From the results in table 2 we note that liquidity variable is positively correlation with capital (equity) and with the level of concentration. However, liquidity is negatively related to size and government ownership. The negative relationship between risk as measured by the standard deviation of return on asset and size indicate that the larger banks, the riskier is the bank, and the larger the government ownership by banks.

Table 1. Descriptive Statistics

\begin{tabular}{lcc}
\hline & Mean & Std. Deviation \\
\hline LTG & .3593 & .33345 \\
$\sigma_{\text {ROA }}$ & .9404 & .73690 \\
GGDP & 6.1804 & 4.18937 \\
EQUITY & .1465 & .09359 \\
LnTA & 15.9665 & 1.98430 \\
INF & 3.32 & 4.687 \\
ROA & .0884 & 1.15809 \\
CON & .5061 & .12335 \\
lag(LTG) & .3425 & .22602 \\
GO & .2336 & .18982 \\
\hline
\end{tabular}


Table 2. The correlation Matrix

\begin{tabular}{|c|c|c|c|c|c|c|c|c|c|c|}
\hline & LTG & $\sigma_{\mathrm{ROA}}$ & GGDP & EQUITY & LnTA & INF & ROA & $\mathrm{CON}$ & lagLTG & $\mathrm{GO}$ \\
\hline LTG & 1.00 & & & & & & & & & \\
\hline$\sigma_{\mathrm{ROA}}$ & .059 & 1.00 & & & & & & & & \\
\hline GGDP & .016 & -.01 & 1.00 & & & & & & & \\
\hline EQUITY & .370 & .142 & .042 & 1.00 & & & & & & \\
\hline LnTA & -.13 & -.127 & .092 & -.39 & 1.00 & & & & & \\
\hline INF & .064 & .011 & .56 & .023 & .33 & 1.00 & & & & \\
\hline ROA & -.017 & .053 & .046 & -.003 & .001 & -.028 & 1.00 & & & \\
\hline $\mathrm{CON}$ & .524 & .256 & .205 & .134 & -.279 & .191 & -.027 & 1.00 & & \\
\hline $\operatorname{lag}(\mathrm{LTG})$ & .56 & -.02 & .014 & -.057 & -.097 & .106 & -.013 & .315 & 1.00 & \\
\hline GO & -.029 & -.27 & .026 & -.087 & .406 & .077 & -.014 & -.46 & -.001 & 1.00 \\
\hline
\end{tabular}

Table 3 shows the results of regressing the bank micro and macro factors on liquidity for the sample of banks under investigation. The model seems fits the data very well: the $\mathrm{R}^{2}$ is 0.52 . The results suggest that the higher the capital ratio the higher the liquidity created by banks. The positive and statistically significant relationship between capital (EQUITY) and liquidity creation is consistent with the literature that bank capital increases bank liquidity through its ability to absorb risk.

The results also show that bank size and the level of previous liquidity are significant in determining the liquidity created by these banks. The larger the bank size, and the higher the liquidity created by the bank in previous period, the higher the liquidity created. Results also show a negative and significant relationship between bank profitability as measured by return on assets and banks' liquidity created. This might indicate either an increase in cost for these banks or an increase in the amount of unpaid credit by bank customers.

As for the macroeconomic factors, none of the indicators we chose show a significant relationship to liquidity created by the banking sector. The coefficient on stock market capitalization is negative, however, insignificant. This implies that stock markets in the GCC region do not complement the banking sector. This is expected since the economy in the GCC region is classified as a bank-based economy where banks control most of the financial flows and possess most of the financial assets. The capital markets, however, are still undeveloped. The results on government ownership, is negative and insignificant. Government ownership does not seem to affect the liquidity of the banks

Table 3. Results of Regression Analysis with dependent variable is Liquidity creation for a sample of 44 GCC commercial Banks over the period 1998-2008

\begin{tabular}{llccc}
\hline Model & & & & \\
& & $\mathrm{B}$ & $\mathrm{t}$ & Sig. \\
\hline & (Constant) & -.915 & -5.094 & .000 \\
& $\sigma_{\text {ROA }}$ & .009 & .501 & .617 \\
GGDP & .003 & .750 & .454 \\
EQUITY & 1.786 & 11.483 & .000 \\
LnTA & .037 & 4.149 & .000 \\
INF & -.003 & -.808 & .420 \\
ROA & -.047 & -4.15 & .000 \\
CON & .072 & .492 & .623 \\
SCAP & $-3.105 \mathrm{E}-7$ & -1.133 & .258 \\
lag(LTG) & 1.176 & 12.980 & .000 \\
GO & -.046 & -.53 & .59 \\
\hline
\end{tabular}

Adj $R^{2}=.52$

$\mathrm{F}=34.215 \quad$ Sign. $=.000 \quad \mathrm{DW}=1.91$

\section{Summary and Conclusions}

This paper uses a simple measure of liquidity creation to examine empirically the effect of bank capital and other micro and macro-characteristics on liquidity. Also, we study the role of banks' Government ownership in 
affecting the liquidity level of banks in our sample. We apply the analysis to data from a sample of 43 banks operating in 6 of the countries comprising the GCC market over the period 1998-2008.

Our results indicate a positive and significant relationship between bank capital and liquidity, consistent with the literature that bank capital increases bank liquidity through its ability to absorb risk. The negative and significant relationship between the profitability as measured by the return on asset and liquidity implies either an increase in the costs incurred by these banks or by an increase in loan losses. In addition, the results might suggest that financial markets in the area are not complementing the financial institutions.

\section{References}

Akash Deep, \& Guido Schaefer. (2004). Are Banks Liquidity Transformers? RWP04-022, Harvard University.

Allen N. Berger, \& Christa H.S. Bouwman. (2008). Financial Crises and Bank Liquidity.

Allen, F., \& Douglas Gale. (2004). Financial intermediaries and markets. Econometrica, 72, 1023-1061. http://dx.doi.org/10.1111/j.1468-0262.2004.00525.x

Arturo Estrella, Sangkyun Park, \& Stavros Peristiani. (2000). Capital Ratios as Predictors of Bank Failure. FRBNY Economic Policy Review.

Berger, Allen N., \& Gregory F. Udell. (1994). Did risk-based capital allocate bank credit and cause a 'credit crunch' in the United States? Journal of Money, Credit, and Banking, 26, 585-628. http://dx.doi.org/10.2307/2077994

Bhattacharya, Sudipto, \& Anjan V. Thakor. (1993). Contemporary banking theory. Journal of Financial Intermediation, 3, 2-50. http://dx.doi.org/10.1006/jfin.1993.1001

Coval, Joshua D., \& Anjan V. Thakor. (2005). Financial intermediation as a beliefs-bridge between optimists and pessimists. Journal of Financial Economics, 75, 535-569. http://dx.doi.org/10.1016/j.jfineco.2004.02.005

Deep, Akash, \& Guido Schaefer. (2004). Are banks liquidity transformers? Harvard University working paper (May).

Diamond, Douglas W. (1984). Financial intermediation and delegated monitoring. Review of Economic Studies, 1, 3-414. http://dx.doi.org/10.2307/2297430

Diamond, Douglas W., \& aghuram G. Rajan. (2000). A Theory of bank Capital. Journal of Finance, December.

Diamond, Douglas W., \& Philip H. Dybvig. (1983). Bank runs, deposit insurance, and liquidity. Journal of Political Economy, 91, 401-419. http://dx.doi.org/10.1086/261155

Gatev, Evan, Til Schuermann, \& Philip E. Strahan. (2005). How do banks manage liquidity risk? Evidence from the equity and deposit markets in the fall of 1998, in Mark Carey and Rene Stulz, eds., Risks of Financial Institutions, Chicago: University of Chicago Press. http://www.nber.org/papers/w12234.pdf?new_window=1

Gorton, Gary, \& Andrew Winton. (2000). Liquidity Provision, the Cost of Bank Capital, and the Macroeconomy. Working paper, University of Minnesota. http://papers.ssrn.com/sol3/papers.cfm?abstract_id=253849.

Hancock, Diana, Andrew J. Laing, \& James A. Wilcox. (1995). Bank balance sheet shocks and aggregate shocks: their dynamic effects on bank capital and lending. Journal of Banking and Finance, 19, 661-77. http://dx.doi.org/10.1016/0378-4266(94)00147-U

Kashyap, Anil K., Raghuram G. Rajan, \& Jeremy C. Stein. (2002). Banks as liquidity providers: an explanation for the coexistence of lending and deposit-taking. Journal of Finance, 57, 33-73. http://dx.doi.org/10.1111/1540-6261.00415

Peek, Joe, \& Eric S. Rosengren. (1995). The capital crunch: neither a borrower nor a lender be. Journal of Money, Credit and Banking, 27, 625-38. http://dx.doi.org/10.2307/2077739

Shepheard-Walwyn, Tim, \& Robert Litterman. (1998). Building a Coherent Risk Measurement and Capital Optimization Model for Financial Firms. Federal Reserve Bank of New York Economic Policy Review, 4(3), 171-82.

Skander J. Van den Heuvel. (2007). The Welfare Cost of Bank Capital Requirements. The Wharton School, University of Pennsylvania. http://fic.wharton.upenn.edu/fic/papers/07/0719.pdf 